\title{
PENGARUH PENAMBAHAN SUSU SAPI TERHADAP KADAR ASAM LAKTAT \\ PADA PEMBUATAN YOGHURT JAGUNG MANIS OLEH Streptococcus thermophillus DAN Lactobacillus bulgaricus
}

\section{EFFECT OF ADDITION LEVELS AGAINST MILK COW LACTIC ACID SWEET CORN ON MAKING YOGHURT BY Streptococcus thermophillus AND Lactobacillus bulgaricus}

\author{
ARYATI ABDUL ${ }^{1}$, SYAMS. KUMAJI ${ }^{1}$, FAISAL DUENGO ${ }^{1,}$ \\ ${ }^{1} J u r u s a n$ Biologi, Fakultas Matematika dan Ilmu Pengetahuan Alam, Universitas Negeri \\ Gorontalo. Jl. Jendral Sudirman 06 Kota Gorontalo, Gorontalo, Indonesia. \\ aryatiabdul@gmail.com; syam_bio@ung.ac.id.dan faisalduengo51@gmail.com
}

\begin{abstract}
Abstrak
Penelitian ini bertujuan untuk melihat pengaruh penambahan susu sapi terhadap kadar asam laktat pada pembuatan yoghurt jagung manis oleh Streptococcus thermophillus dan Latobacillus bulgaricus. Penelitian ini merupakan penelitian eksperimen dengan menggunakan 7 perlakuan $(0 \%, 10 \%, 20 \%, \quad 30 \%, 40 \%, 50 \%$ dan $60 \%)$ dan 4 ulangan. Data dianalisis menggunakan analisis varians (ANAVA) dengan taraf kepercayaan $0.05 \%$ untuk membedakan antar perlakuan digunakan uji beda nyata terkecil (BNT). Hasil penelitian menunjukan penambahan susu sapi berpengaruh terhadap kadar asam laktat pada pembuatan yoghurt jagung manis oleh Streptococcus thermophillus dan Latobacillus bulgaricus.
\end{abstract}

Kata Kunci:Susu Sapi, Sari Jagung, Asam Laktat, Yoghurt

\begin{abstract}
This study aims tolook at the effect of adding milk to lactic acid levels in the manufacture of yoghurt sweet corn by Streptococcus thermophillus and Latobacillus bulgaricus. This study was an experimental study using 7 treatments $(0 \%, 10 \%, 20 \%, 30 \%, 40 \% 50 \%$ and $60 \%)$ and 4 replicates. Data were analyzed using analysis of variance (ANOVA) with a confidence level of $0.05 \%$ to distinguish between treatment sused test least significant difference (LSD). The results showed the addition of cow's milk effect on the levels of lactic acid in yogurt manufacture of sweet corn by Streptococcus thermophillus and Latobacillus bulgaricus
\end{abstract}

Keywords: Cow's Milk, Corn Juice, Lactic Scid, Yogurt 


\section{Pendahuluan}

Jagung merupakan salah satu komoditi yang banyak dan murah harganya terutama ketika panen. Salah satu jenis jagung yang banyak dimanfaatkan adalah jagung manis, misalnya dikonsumsi sebagai jagung rebus,jagung bakar dan olahan kue basah atau diolah menjadi tepung dan bahan pakan ternak.Sebelumnya masih banyak produk yang dapat dihasilkan olahan jagung, namun belum banyak diketahui masyarakat.Hal ini disebabkan karena belum tersebar dan berkembangnya informasi mengenai inovasi yang dapat menarik perhatian masyarakat untuk memanfaatkan jagung sebagai bahan pangan.Oleh karena ituperluadanya penganekaragaman bentuk olahan jagung terutama jagung muda yang lebih bervariatif dan dapat menarik perhatian masyarakat. Sehingga hal ini dapat memberikan nilai ekonomi pada jagung itu sendiri, salah satu upaya yang dapat dilakukan adalah dengan membuat sari jagung manis.

Sari jagung manis merupakan cairan yang berasal dari ekstrak biji jagung dengan atau tanpa penambahan bahan lain. Manfaat sari jagung manis adalah dapat memulihkan energy dalam waktu cepat, menjaga kesehatan mata, hati, lambung usus, dan dapat mengobati penyakit diabetes dikarenakan jagung manis mengandung fruktosa bukan glukosa. Sebagai minuman, sari jagung diharapkan dapat menyegarkan dan menyehatkan tubuh karena tidak mengandung kolesterol (Satiarini, 2006). Akan tetapi dalam pembuatan sari jagung sering terkendala oleh cepat rusaknya susu akibat aktifitas mikroba patogen, maka diperlukan suatu upaya untuk mencegah kerusakan pada sari jagung, misalnya dengan proses fermentasi sehingga menghasilkan yoghurt jagung (Satiarini, 2006).

Yoghurt jagung merupakan salah satu kreasi yoghurt berbahan dasar sari jagung yang diolah dengan cara yang sama seperti pembuatan yoghurt pada umumnya. Namun dalam pembuatan yoghurt jagung,yang perlu diperhatikan adalah kandungan karbohidrat yang terdapat didalam biji jagung tersebut. Menurut Polina (dalam Lutfhianto dkk, 2013) bahwa karbohidrat sederhana yang terdapat pada jagung manis sebesar 2-3\% sedangkan karbohidrat kompleks yang terdiri dari pati merupakan komponen terbesar yang terdapat dalam butir jagung manis yaitu berjumlah $72 \%$. Pati ini merupakan salah satu sumber karbon bagi bakteri asam laktat seperti Streptococcus thermophilus dan Lactobacillus bulgaricus. Akan tetapi, bakteri asam laktat membutuhkan waktu yang relative lama dalam menguraikan pati tersebut menjadi gula sederhana, sehingga dalam pembuatan yoghurt dari jagung ini dibutuhkan tambahan gula sederhana berupa laktosa. Salah satu sumber laktosa. terdapat pada susu sapi. (Syamsir dalam Aulia2012).

Susu sapi merupakan cairan yang berasal dari sapi yang sehat dan bersih, yang diperoleh dengan cara yang benar,yang kandungan alaminya tidak ditambah atau dikurangi sesuatu apapun dan belum mendapat pelakuan.(Dirkeswan,1983). Susu sapi mengandung laktosa yang berperan sebagai sumber karbon atau sumber energy utama untuk pertumbuhan bakteri Streptococcus thermophilus dan Lactobacillus bulgaricus dan merupakan substrat pada proses fermentasi.Laktosa dapat dihidrolisis menjadi glukosa dan galaktosa oleh enzim $\beta$ D galaktosidase (lactase). Kemampuan produksi enzim ini pada bakteri Streptococcus thermophilusdan Lactobacillus bulgaricus memberikan keuntungan dalam hal kemampuan untuk menghasilkan produk-produk fermentasi salah satunya adalah asam laktat (Widodo 2003). Berdasarkan hasil pra penelitian yang dilakukan diperoleh bahwa penambahan susu sapi dengan konsentrasio \%, 10\%, $20 \%, 30 \%, 40 \%, 50 \%$, sampai penambahan $6 \%$ pada fermentasi sari jagung dapat meningkatkan total asam laktat. 
Asam laktat merupakan salah satu produk yang dihasilkan selama proses fermentasi. Menurut Frederick dan Frederick, (dalam Pramudyanti, dkk 2004), bahwa asam laktat adalah asam organic yang diproduksi oleh manusia, hewan, tumbuhan dan mikroorganisme yang memiliki beberapa keuntungan fisiologis seperti daya cerna yang lebih baik, meningkatkan penggunaan kalsium, fosfor, dan besi, merangsang sekresi cairan lambung,serta sebagai sumber energy dalam proses respirasi anaerob. Selanjutnya menurut Widodo (2002) bahwa asam laktat dari yoghurt dapat merangsang gerakan peristaltik hampir pada semua bagian pada saluran pencernaan,selain itu asam laktat dapat mengurangiatau membunuh bakteri patogendan menekan produksi senyawa-senyawa berbahaya yang diproduksi oleh bakteri patogen

\section{Metode Penelitian}

Penelitian ini dilaksanakan di Laboratorium Mikrobiologi Jurusan Biologi Fakultas Matematika dan IPA Universitas Negeri Gorontalo,bselamab3 bulan mulai dari tahap persiapan sampaibdenganbtahap penyusunan laporan hasilbpenelitian, yaitu bulan FebruariApril 2015.Metode yang digunakan dalam penelitian ini adalah metode eksperimen, dan rancangan yang digunakan adalah Rancangan Acak Lengkap (RAL) dengan tujuh peralakuan dan empat kali pengulangan. Adapun perlakuan dalam penelitian ini yaitu:

1. Perlakuan $A$ : Sari jagung tanpa penambahan susu sapi

2. Perlakuan $B: S a r i j a g u n g$ dengan penambahan susu sapi $10 \%(\mathrm{v} / \mathrm{v})$

3. Perlakuan C:Sari jagung dengan penambahan susu sapi $20 \%(\mathrm{v} / \mathrm{v})$

4. Perlakuan D:Sari jagung dengan penambahan susu sapi $30 \%(\mathrm{v} / \mathrm{v})$

5. Perlakuan E:Sari jagung dengan penambahan susu sapi $40 \%(\mathrm{v} / \mathrm{v})$

6. Perlakuan $F: S a r i$ jagung dengan penambahan susu sapi $50 \%(\mathrm{v} / \mathrm{v})$

7. Perlakuan $\mathrm{G}$ :Sari jagung dengan penambahan susu sapi $60 \%(\mathrm{v} / \mathrm{v})$

Bahan yang digunakan dalam penelitian ini adalah plain yoghurt yang mengandung Lactobacillus bulgaricus dan Streptococcus thermophilus, susu bear brand, aquades, alcohol $75 \%, \mathrm{NaOH} 0.1 \mathrm{~N}$,indicator PP (Fenolptalein), Nutrien Agar, $\mathrm{NaCl}$ fisiologi dan alat yang digunakan dalam penelitian ini adalah pipet, erlen meyer, mikro Biurette, timbangan analitik kepekaan 0.0001gram,gelas ukur, batang pengaduk, gelas piala, belender, pisau, saringan, inkubator, hotplate, tabung reaksi, cawan petri,autoclave, almunium foil, indicator $\mathrm{pH}$, lemari pendingin,laminar air flow dan mikro pipet

Prosedur kerja dalam penelitian ini meliputi beberapa tahapan sebagai berikut:

a. Penyiapan Plain Yoghurt

Plain yoghurt yang sudah diinokulasi dengan Streptococcus thermophilus dan Lactobacillus bulgaricus diperoleh dari LIPI Bandung, kemudian disimpan pada suhu kurangl ebih $4^{\circ} \mathrm{C}$.

b. Pembuatan Sari Jagung Manis

Pipilan biji jagung manis dibersihkan kemudian direbus pada saat suhu air mencapai $100^{\circ} \mathrm{C}$ selama 9 menit kemudian diangkat dan ditiriskan. Jagung yang telah matang di blender bersama air rebusan jagung dengan perbandingan 1:2 sampaih alus setelah itu difiltrat untuk memisahkan sari jagung dari ampas jagung. Sari jagung manis ini yang akan digunakan sebagai substrat plain yoghurt (Amrinola dalam Eliyasmi, dkk 2013). 
c. Pembuatan Yoghurt Jagung

Sari jagung yang telah dibuat dimasukkan kedalam gelas piala dan ditambahkan dengan susu bear brand berdasarkan variasi perlakuan, yaitu $10 \% ; 20 \% ; 30 \%, 40 \%, 50 \%$,dan 60 $\%$ (v/v) serta tanpa penambahan susu bear brand, (kontrol). Kemudian ke dalam gelas piala tersebut ditambahkan plain yoghurt sebanyak $5 \mathrm{ml}$ dan selanjutnya diinkubasi dalam inkubator padasuhu $37^{\circ} \mathrm{C}$ selama16 jam. Setelah proses inkubasi dilakukan kemudian dilanjutkan dengan proses analisis kadar asam laktat dengan menggunakan metode titrasi.

d. Pengukuran Nilai pH

Pengukuran $\mathrm{pH}$ menggunakan $\mathrm{pH}$ indicator yang dilakukan sebelum dan sesudah fermentasi untuk mengetahui kadar keasaman dari sari jagung.

e. Perhitungan Total Plate Count (TPC)

Mengambil sebanyak $0.5 \mathrm{ml}$ yoghurt dan memasukkannya kedalam larutan yang berisi $\mathrm{NaCL}$ fisiologis steril sebanyak $4.5 \mathrm{ml}$, suspense yang diperoleh dipindahkan ke dalam tabung steril dan divortex sampai homogen, selanjutnya diambil sebanyak $0.5 \mathrm{ml}$ dengan menggunakan dispo dan mengencerkan menjadi $10^{-1}$ dengan menambahkan NaCL fisiologi sebanyak $4.5 \mathrm{ml}$, selanjutnya dibuat pengenceran $10^{-2}$,yaitu mengambil0.5 $\mathrm{ml}$ dari hasil pengenceran sebelumnya menambahkan $\mathrm{NaCL}$ fisiologi sebanyak $4.5 \mathrm{ml}$, selanjutnya dibuat pengenceran $10^{-3}$ yaitu mengambil $0.5 \mathrm{ml}$ dari hasil pengenceran sebelumnya menambahkan $\mathrm{NaCL}$ fisiologi sebanyak $4.5 \mathrm{ml}$.dari masing-masing pengenceran diambil suspensi sebanyak $1 \mathrm{ml}$ ke dalam cawan petri kemudian dimasukkan media Nutrient Agar(NA)yang bersuhu $\pm 45^{\circ} \mathrm{C}$ sebanyak 15 mldandibiarkansampai memadat. Selanjutnya diinkubasi dalam inkubator pada suhu $37^{0} \mathrm{C}$ selama1 $\times 24$ jam.

Setelah masa inkubasi dilanjutkan proses perhitungan jumlah koloni bakteri dengan menggunakan rumus sebagaiberikut(Fardiaz, 1989):

$$
\text { Koloni per mil }=\text { Jumlah koloni } x \frac{1}{\text { Faktor pengenceran }}
$$

Teknik pengumpulan data dalam penelitian ini adalah pengukuran kadar asam laktat dengan cara, yaitu darimengambil $10 \mathrm{~mL}$ yoghurt dan dimasukkan ke dalam erlen meyer untuk dititrasi dengan $\mathrm{NaOH} 0.1 \mathrm{~N}$. Dalam proses titrasi ini yang digunakan larutan indikator,yaitu fenolptalein sebanyak 5 tetes dengan perubahan warna dari tak berwarna menjadi merah muda.Setelah diperoleh data selanjutnya dimasukkan dalam rumus sebagai berikut (Hadiwiyoto, 1994).

$$
\% \text { asam laktat }=\frac{A \times 0,009 \times 100 \%}{B}
$$

Keterangan : $A=$ Volume $\mathrm{NaOH}$ yang terpakai

$\mathrm{B}=$ Volume sampel yang diamati

$0,009=$ BE asam Laktat

Teknik analisis data yang digunakan pada penelitian ini yaitu dengan analisis varians (ANAVA).Uji Fatau (Sig<0.05) digunakan apabila terdapat pengaruh susu sapi terhadap kadar asam laktat pada pembuatan yoghurt jagung dalam hal ini hipotesis 1 terbukti maka dilanjutkan keuji BNT untuk menguji hipotesis 2 terkait konsentrasi optimum susu skim yang baik dengan melihat signifikasi dari tiap perlakuan yang diberikan. 


\section{Hasil danPembahasan}

\section{a. GambaranYoghurt Jagung Manis}

Yoghurt jagung manis merupakan salahsatu jenis yoghurt berbahan dasar jagungyang diolah dengan cara yang sama seperti pembuatan yogurt pada umumnya. Dalam penelitian ini sari jagung manis dibuat dengan menambahkan susu sapi sebagai sumber karbon untuk bakteri asam laktat dengan pemberian kosentrasi yang berbeda. Sumber karbon ini digunakan oleh bakteri asam laktat selama proses fermentasi sari jagung sehingga menghasilkan asam laktat.

Asam laktat yang dihasilkan dalam pembuatan sari jagung manis juga dapat mempengaruhi perubahan derajat keasaman $(\mathrm{pH})$, semakin tinggi konsentrasi sususapi maka derajat keasaman $(\mathrm{pH})$ setelah fermentasi semakin rendah. Berdasarkan hasil penelitian,rata-ratapH sari jagung manis sebelum fermentasi adalah 6 dan setelah fermentasi pHnya adalah 5.

Penurunan $\mathrm{pH}$ dan penambahan susu sapi dapat mengoptimalkan pertumbuhan daribakteri asam laktat, semakin tinggi konsentrasi susu sapi semakin banyak jumlah koloni bakteri, sebagaimana data hasil perhitungan koloni bakteri pada penelitian ini terdapat perbedaan jumlah koloni bakteri dari setiap kosentrasi yaitu berkisar antara $2 \mathrm{x}$ $10^{3}-6,2 \times 10^{5} \mathrm{CFU} / \mathrm{ml}$.

\section{b. Hasil Pengukuran Kadar Asam Laktat PadaYoghurt Jagung Manis}

Berdasarkan hasil penelitian untuk mengetahui pengaruh penambahan susu sapi terhadap kadar asam laktat pada fermentasi sari jagung manis diperoleh hasil seperti pada Tabel1.

Tabel1. Rata-rata Kadar Asam Laktat pada Pembuatan Yoghurt Jagung Manis

\begin{tabular}{|c|c|}
\hline Konsentrasi sususapi $(\%(\mathbf{v} / \mathbf{v})$ & Rata- ratakadar asamlaktat $(\%)$ \\
\hline $0 \%$ & 0,067725 \\
\hline $10 \%$ & 0,10012 \\
\hline $20 \%$ & 0,14017 \\
\hline $30 \%$ & 0,16762 \\
\hline $40 \%$ & 0,20138 \\
\hline $50 \%$ & 0,16898 \\
\hline $60 \%$ & 0,14420 \\
\hline
\end{tabular}

Berdasarkan Tabel 1. Dapat dilihat bahwa penambahan susu sapi dengan kosentrasi $10 \%$ sampai kosentrasi $40 \%$ dapat meningkatkan total asam laktat dalam pembuatan yoghurt jagung manis. Hal ini ditunjukkan dengan rata- rata kadar asam laktat tertinggi adalah 0,20138 pada kosentrasi susu sapi $40 \%$. Tetapi pada konsentrasi $50 \%$ dan $60 \%$ terjadi penuruan kadar asam laktat. Untuk memperjelas perbedaan rata-rata kadar asam laktat untuk setiap perlakuan, maka dapat disajikan dalam bentuk histogram pada Gambar 1. 


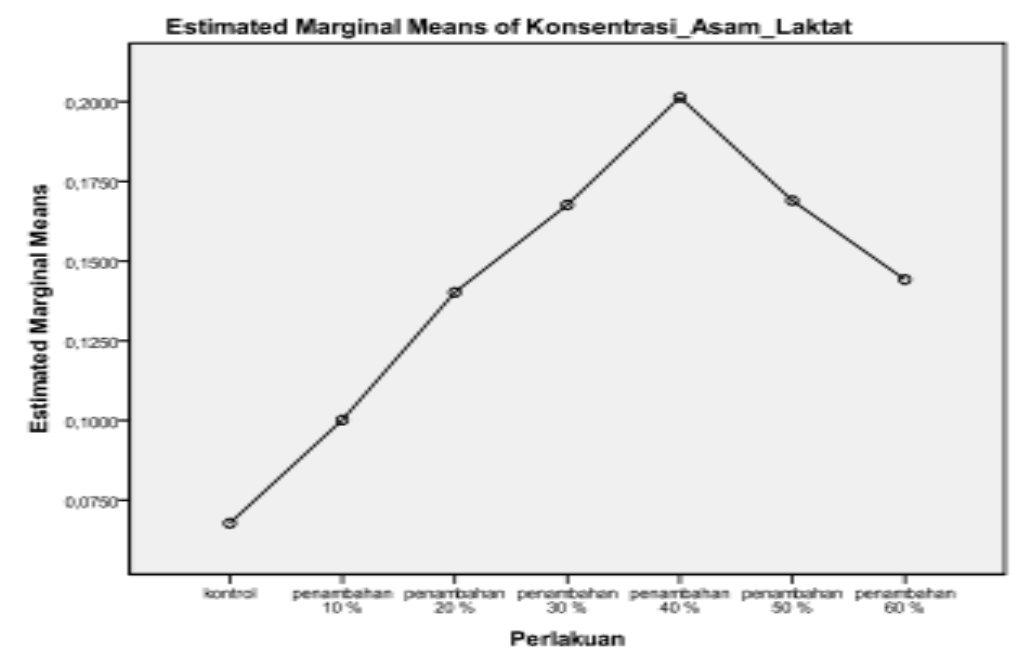

Gambar 1.Histogram Rata-Rata Kadar AsamLaktat Pada Pembuatan Sari Jagung Manis

Selanjutnya dari hasil uji $\mathrm{F}$ dengan menggunakan modeloneway ANOVA diperoleh nilai sig. sebesar 0,000 dibawah nilai alfa 0,05. (Bila dibandingkan nilai Fhitung perlakuan sangat besar yaitu 140,023 sedangkan nilai $\mathrm{F}$ dalam table dengan $\mathrm{V} 1=(7-1)=6$ dan $\mathrm{V} 2=(7-$ 1) $x 4=24$ dengan alfa sebesar 0,05 yaitu 2,51.) maka Ho ditolak dan $\mathrm{H} 1$ diterima, hal ini berarti bahwa terdapat pengaruh penambahan susu sapi terhadap kadar asam laktat pada pembuatan sari jagung manis. Kemudian untuk melihat perbedaan dari masing-masing perlakuan maka digunakan analisis beda nyata terkecil (BNT).

\section{Pembahasan}

Fermentasi sari jagung manis merupakan salah satu jenis fermentasi asam laktat dengan menggunakan bakteri asam laktat. Streptococcus thermophilus dan Lactobacillus bulgaricus termasuk salah satu jenis bakteri asam laktat, yang mampu mengubah karbo hidrat menjadi asam laktat.Proses fermentasi sari jagung manis dalam penelitian ini ditambahkan dengan plain yoghurt bakteri Streptococcus thermophilus dan Lactobacillus bulgaricus serta susu sapi sebagai sumber karbon (laktosa) kemudian diinkubasi dan hasilnya adalah susu fermentasi sari jagung manis yang mengandung asam laktat sebagai hasil dari aktivitas bakteri asam laktat tersebut.

Dari hasil penelitian yang dilakukan diperoleh bahwa penambahan susu sapi berpengaruh terhadap produksi asam laktat pada fermentasi sari jagung manis dengan menggunakan bakteri Streptococcus thermophilus dan Lactobacillus bulgaricus. Hal tersebut disebabkan karena susu sapi mengandung laktosa yang merupakan gula sederhana sebagai sumber energy untuk pertumbuhan bakteri asam laktat. Adanya asam laktat di dalam fermentasi sari jagung manis terutama disebabkan oleh aktivitas bakteribakteri pembentuk asam. Bakteri tersebut dapat merubah laktosa menjadi asam laktat dan timbulnya asam laktat dapat menurunkan pH susu. Menurut Rahayu (dalam Afriani, 2010), bahwa kadar asam fermentasi susu dipengaruhi oleh aktivitas bakteri yang merubah gula (laktosa) menjadi asam laktat, walaupun laktosa susuyang diubah menjadi asam laktat hanya sekitar $30 \%$ sedangkan sisanya (70\%) masih dalam bentuk laktosa.Lebih lanjut Buckleet al, (1987) menyatakan bahwa suasana asam diakibatkan oleh proses fermentasi susu, yaitu perubahan laktosa menjadi asam laktat oleh aktivitas enzim yang 
dihasilkan oleh bakteri asam laktat serta senyawa-senyawa yang terkandung dalam susu seperti albumin, kasein sitrat, dan fosfat.

Proses pengubahan glukosa menjadi asam laktat berlangsung dalam keadan anaerob atau tanpa oksigen. Tahap pengaktifan pertama terjadi proses phosforilasi D-Glukosa oleh ATP sehingga terbentuk molekul Glukosa-6-phosfat, reaksi ini dibantu oleh enzim glukokinase (hati) dengan kofaktor $\mathrm{Mg}^{2+}$ dan $\mathrm{Mn}^{2+}$.Selanjutnya, molekul tersebut akan mengalami perubahan gugus fungsi oleh enzim phosfoglukoisomerase dan kofaktor $\mathrm{Mg}^{2+}$ menjadi fruktosa-6-phosfat. Tahap selanjutnya ialah proses pengaktifan kedua pengubahan fruktos-6-phosfat menjadi fruktosa-1,6- diphosfat yang dikatalis oleh enzim phosfofruktokinase dan kofaktor $\mathrm{Mg}^{2+}$.

Proses selanjutnya yaitu molekul fruktosa-1,6-diphosfat akan diubah menjadi 2 molekul triosa phosfat oleh enzima Idolase dalam bentuk 1 molekul dihidroksi aseton phosfat dan 1 molekul Gliseraldehid-3- phosfat. Dihidroksi aseton yang terbentuk kembali akan mengalami perubahan gugus fungsi menjadi Gliseraldehid-3-phosfat, dengan demikian akhirnya akan terbentuk 2 molekul Gliseraldehid-3-phosfat. Setiap molekul Gliseraldehid-3-phosfat akan mengalami dehidroginase oleh enzim gliseraldehid-3phosfatdehidroginase, $\mathrm{NADH}^{+}$dan ion phosfat sehingga terbentuk molekul1,3phosfogliserat dan NADHH.

Tahap selanjutnya yaitu tahap penyimpanan energy pertama dalam bentuk ATP (Adenosin triphosfat) hasil darperubahan1,3- phosfogliserat menjadi 3-phosfogliserat oleh bantuan enzim phosfogliserat kinasedan kofaktor $\mathrm{Mg}^{2+}$. Molekul ini akan mengalami mutasi ionmejadi2- phosfoglierat dengan bantuan enzim phosfgliseromutase.

Enzim enolase akan merubah 2- phosfoglierat menjadi phosfoenolpirufat. Selanjutnya phosfoenolpirufat akan diubah menjadi asam piruvat dengan bantuan enzim piruvatkinase. Pada tahap akhir asam piruvat akan diubah menjadi asam laktat dengan oleh bakteri asam laktat dengan bantuan enzim laktat dehidrogenase.

Bakteri asam laktat bersifat fakultatif anaerob. Bakteri ini dapat memfermentasi laktosa menjadi asam laktat, tetapi hanya $1 / 6$ bagian dari asam laktat yang ada dalam susu.Asam laktat yang dibentuknya ini dapat menghambat pertumbuhannya sendiri maupun menghambat pertumbuhan mikroorganisme lainnya. Bakteri asam laktat ini dapat dijadikan sebagai starter kultur untuk pembuatan susu fermentasi seperti yogurt, keju, dan mentega. Berdasarkan sifat fermentasinya bakteri asam laktat dibagi menjadi 2 tipe yaitu asam laktat homofermentatif yaitu apabila terdapat hasil lainnya disamping asam laktat seperti asam asetat, gas dan alkohol maka disebut bakteri asam laktat hetero fermentative (Malaka,2010).

Hasil penelitian menunjukkan bahwa pada perlakuan $40 \%$ menghasilkan kadar asam laktat yang maksimum yakni 0,20138. Selanjutnya untuk kadar asam laktat terendah ditunjukkan pada perlakuan kontrol yakni tanpa penambahan susu sapi $(0 \% \mathrm{v} / \mathrm{v})$,yaitu 0,067725. Hal ini disebabkan karena bakteri Streptococcus thermophilusdan Lactobacillus bulgaricus tersebut harus beradaptasi terlebih dahulu dan memerlukan energy yang lebih banyak untuk mensintesis enzim yang diperlukan dalam menguraikan karbohidrat kompleks (polisakarida) yang terdapat pada susu jagung menjadi glukosa,yang nantinya akan digunakan dalam fermentasi asam laktat, sehingga untuk menghasilkan asam laktat membutuhkan waktu yang lebih lama jika dibandingkan dengan perlakuan dengan penambahan karbohidrat sederhana. 
Kadar asam laktat yang dihasilkan pada perlakuan $20 \%$ dan $60 \%, 30 \%$ dan $50 \%$ menunjukkan hasil yang tidak berbeda nyata hal ini disebabkan karena terjadinya penurunan $\mathrm{pH}$ dan penambahan gula yang berlebihan menyebabkan penurunan aktivitas bakteri asam laktat. Menurut Gianti dan Evanuarini (2011) semakin tinggi kadar gula (laktosa) yang ditambahkan cenderung mempengaruhi $\mathrm{pH}$ susu fermentasi dan menyebabkanpenurunan aktivitas starter.Karena konsentrasi medium yang pekat menyebabkan mikroorganisme mengalami osmosis dan perkembangbiakannya terhambat akibatnya pembentukan asam laktat semakin menurun. Selain itu gula yang ditambahkan kedalam bahan pangan dengan konsentrasi tinggi menyebabkan sebagian besar air berkurang sehingga tidak cukup untuk memenuhi kebutuhan air untuk mikroorganisme.

Menurut Standar Nasional Indonesia (1995) bahwa kadar asam laktat untuk yoghurt adalah $0,5-2,0 \%$. Namun dalam penelitian ini tidak diperoleh kadar asam laktat sesuai dengan SNI karena disebabkan oleh beberapa factor diantaranya adalah jumlah starter, macam starter dan kemampuan starter dalam membentuk asam laktat. Hal ini sesuai dengan pernyataan Tamime dan Robinson (dalam Afriani, 2010) bahwa kecepatan terbentuknya asam laktat dan tinggi rendahnya kadar asam laktat tergantung pada jumlah starter, macam starter dan kemampuan starter yang digunakan dalam membentuk asam laktat.

Berdasarkan hasil penelitian ini menujukkan terdapat hubungan antara peningkatan konsentrasi susu sapi yang digunakan dengan peningkatan kadar asam laktat pada batas konsentrasi tertentu dan penurunan nilai $\mathrm{pH}$ yang merupakanfaktor pendukung pertumbuhan Streptococcus thermophilusdan Lactobacillus bulgaricus yang lebih aktif pada $\mathrm{pH}$ optimum. Sari jagung manis yang awalnya mempunyai $\mathrm{pH} 6$ setelah difermentasi oleh bakteriStreptococcus thermophilusdan Lactobacillus bulgaricus mengalami penurunan $\mathrm{pH}$ menjadi 5. Penurunan $\mathrm{pH}$ terjadi karena pada saat fermentasi, bakteri asam laktat akan menghasilkan asam laktat sehingga semakin banyak asam laktat yang dihasilkan,maka $\mathrm{pH}$ semakin turun. Menurut Winarno dan Fernandez (2007),bakteri asam laktat,pada umumnya menghasilkan sejumlah besar asam laktat dari fermentasi substrat energi karbohidrat. Asam laktat yang dihasilkan dari proses metabolisme karbohidrat akan berpengaruh pada penurunan nilai $\mathrm{pH}$ lingkungan pertumbuhannya dan menimbulkan rasa asam. Total asam laktat yang dihasilkan berhubungan dengan nilai $\mathrm{pH}$ semakin tinggi nilai asam laktat yang dihasilkan,maka semakin rendah nilai $\mathrm{pH}$.

\section{Kesimpulan}

Berdasarkan hasil penelitian dapat disimpulkan bahwa :

1. Terdapat pengaruh penambahan susu sapi terhadap kadar asam laktat pada pembuata yoghurt jagung manis.

2. Konsentrasi susu sapi yang baik untuk mendapatkan kadar asam laktat optimum diperoleh pada perlakuan $40 \%$. 


\section{DaftarPustaka}

Afriani,2010. Pengaruh penggunaan starter bakteri asam laktat Lactobacillus plantarum dan Lactobacillus fermentum terhadap total bakteri asam laktat, kadar asam dan nilai $\mathrm{pH}$ dadih susu sapi. Jurna IIImiah IImu-IImu Peternakan.

Aulia, 2012. Formulasi Kombinasi Tepung Sagu dan Jagung Pada Pembuatan Mie. Jurnal Chemica, 12(2).

Becker, W.M. Jane B.Reece and Martin F. Poenie. 1996. The Word of The Cell.By The Benjamin Cummings Publishing Company. Third Edition.

Buckle, K.A., Edwards, R.A., Fleet, G.H., and Wotton, M. 1987. Ilmu Pangan. Penerjamah Hari Purnomo dan Adiono. Universitas Indonesia. Jakarta

Direktorat Kesehatan Hewan, 1983. Manual Kesmavet. No.28/II/1983.Direktorat Kesehatan Hewan, Direktorat Jendral Peternakan, Departemen Pertanian.Jakarta

Eliyasmi,R, Nofrianti,R dan Azima, F. 2013. Pengaruh Penambahan MaduTerhadap Mutu Yoghurt Jagung.Volume ke-2. No 2. Fakultas Teknologi Pertanian Universitas Andalas,Kampus Limau Manis. Padang

Fardiaz,S. 1989. Mikrobiologi Pangan. PAU IPB dengan LSIIPR Bogor.

Hadiwiyoto Suwedo.1994. Teoridan prosedur pengujian mutu susu dan hasil olahannya.Liberty: Yogyakarta

Gianti, I dan H. Evanuarini. 2011. Pengaruh Penambahan Gula dan Lama Penyimpanan Terhadap Kualitas Fisik Susu Fermentasi. Jurnal IImu dan Teknologi Hasil Ternak ,6(1):26-33.

Lutfhianto dkk, 2013. Pengaruh Penambahan Level Ekstrat Jagung Manis (Zeamays saccharat) pada pembuatan susu pasteurisasi terhadap kadar beta karoten dan kesukaan. Jurnal Ilmiah Peternakan, 1(2) :634-638

Malaka, R. 2010. Pengantar Teknologi Susu.Cetakan I Makassar, Masagena Press.

Pramudyanti, I.R, dkk, 2004. Pengaruh pengaturan $\mathrm{pH}$ dengan $\mathrm{CaCO} 3$ terhadap produksi asam laktat dari glukosa oleh Rhizopus oryzae .Jurnal: Bioteknologi,1 (1):19-24

Satiarini, B.2006. Kajian produksi dan profitabilitas pembuatan susu jagung. Fakultas Teknologi Pertanian. Institut Pertanian Bogor. Bogor

Standar Nasional Indonesia. 2009. Yoghurt. SNI 2981 : 2009.

Widodo, W. 2002. Bioteknologi Fermentasi Susu. Malang: Pusat Pengembangan Bioteknologi UMM

Winarno , F. G dan I. E Fernades. 2007. Susu dan produk fermentasinya. M-Brio Press. Bogor 